\title{
ANTESEDEN NIAT UNTUK MEMILIH JASA HALAL BEAUTY CENTER: APLIKASI THEORY OF PLANNED BEHAVIOR DAN PERAN RELIGIUSITAS
}

\author{
Chandra Suparno \\ Fakultas Ekonomi dan Bisnis Universitas Jenderal Soedirman \\ Email: chandrasuparno@gmail.com
}

\begin{abstract}
Abstrak
Tujuan penelitian ini adalah untuk menganalisis pengaruh sikap, norma subjektif, kontrol perilaku terhadap niat untuk memilih jasa halal beauty center, dengan variabel religiusitas Islam sebagai pemoderasi. Jumlah responden yang dilibatkan dalam penelitian ini adalah sebanyak 120 responden dengan menggunakan metode accidental dan purposive sampling. Melalui analisis regresi berganda dan uji Chow, terungkap bahwa sikap dan norma subjektif berpengaruh positif terhadap niat untuk memilih jasa halal beauty center, dan juga ditemukan bahwa peran religiusitas memoderasi hubungan antara sikap, norma subjektif dengan niat untuk memilih jasa halal beauty center.
\end{abstract}

Kata kunci: Theory of Planned Behavior, Religiusitas, Islam, Halal service, Behavioral Intention

\begin{abstract}
This research aims to analyze the influence of attitude, subjective norm, and perceived behavior control towards intention to choose halal beauty center with the Islamic religiousity as the moderating variable. This study took 120 respondents as its samples by using accidental and purposive sampling as the method to collect the sample. Using Multiple Regression Analyis, and Chow test, the results of this study shows that attitude and subjective norm have a positive influence towards intention to choose muslimah beauty center. It also revealed that religiousity moderates the relation between attitude, subjective norm and intention to choose halal beauty center.
\end{abstract}

Keyword: Theory of Planned Behavior, Religiosity, Islam, Halal service, Behavioral Intention

\section{PENDAHULUAN}

Komitmen

beragama

atau religiusitas memiliki peran yang sangat penting dalam hal pembentukan pengetahuan, kepercayaan dan sikap seseorang, yang mana semua hal tersebut melekat dalam setiap individu dan tidak dapat dikesampingkan dalam sebuah kajian kelompok maupun individu (Fam, et.al, 2002). Secara umum, perilaku seseorang dan kehidupannya dapat dipengaruhi oleh agama (Ebaugh 2002; Poloma dan Pendlenton 1990; Sloan, et al. 1999;
Woods, et al. 1999). Begitu pula halnya dalam pembahasan tentang perilaku konsumen, terdapat dua aspek yang menjadi penghubung di antara keduanya, yaitu afiliasi kegamaan dan komitmen beragama (Sun, et.al, 2011). Lebih lanjut, Rehman dan Shabbir (2010) mengungkapkan bahwa pada akhirnya komitmen beragama dapat mempengaruhi dan menentukan arah niat pembelian atau pemilihan suatu produk bagi konsumen (Rehman dan Shabbir, 2010). 
Islam sebagai salah satu agama terbesar di dunia, memiliki seperangkat peraturan yang harus ditaati oleh para pemeluknya, bukan hanya dalam ranah peribadatan, tetapi juga dalam berbagai aspek kehidupan lainnya seperti bagaimana cara berinteraksi dengan orang lain, bagaimana cara berdagang, dan apa yang boleh dan tidak boleh dilakukan dalam kehidupan sehari-hari (Alam, et al, 2011). Setiap aktifitas yang dilakukan oleh seorang muslim, termasuk di dalamnya aktifitas mengkonsumsi segala sesuatu, harus berada dalam koridor legalitas agama yang sering disebut sebagai halal. Konsep halal menjadi penting bagi para praktisi maupun akademisi untuk menelaah isu tersebut, karena merupakan sebuah kunci utama dalam aktivitas konsumsi di dalam komunitas muslim. Senada dengan pernyataan tersebut, Azmi (2005) menyatakan bahwa dewasa ini istilah halal bukan lagi sekadar isu agama, melainkan juga menjadi sebuah kajian dalam sektor bisnis dan perdagangan serta menjadi simbol global dalam hal jaminan kualitas dan pilihan gaya hidup.

Berdasarkan beberapa penelitian yang berhubungan dengan niat pembelian sebuah produk halal, ditemukan bahwa penggunaan Theory of Planned Behavior masih menjadi pilihan sebagai dasar untuk mengukur seberapa besar niat yang muncul, dan juga untuk mengetahui pengaruh dari beberapa faktor yang menjadi anteseden dari teori tersebut, yaitu seperti sikap, norma subjektif, dan kontrol keperilakuan. Peter dan Olson (2000) mendefinisikan niat sebagai suatu proposisi yang menghubungkan antara diri dengan tindakan yang akan dilakukan di masa yang akan datang dalam wujud sebuah keinginan, dimana keinginannya disini tercipta melalui proses pilihan. Norma subjektif didefinisikan oleh Ajzen (2006) sebagai sebuah penilaian atau sebuah reaksi setiap individu terhadap tekanan lingkungan untuk melakukan atau tidak melakukan suatu perilaku tertentu. Sikap mencakup tentang keseluruhan penilaian seseorang terhadap suatu perilaku, dengan dua unsur yang melandasi, yaitu behavioral beliefs dan outcome evaluation. Kontrol keperilakuan diartikan sebagai kepada persepsi seseorang tentang keyakinan terhadap kemampuannya untuk melakukan suatu perilaku tertentu (Ajzen, 2006).

Meski demikian, dari hasil penelaahan beberapa penelitian tersebut, ditemukan adanya perbedaan hasil penelitian. Beberapa diantaranya, Bonne, et al. (2007), meneliti tentang faktor-faktor yang mempengaruhi niat untuk mengkonsumsi daging halal di Perancis. Dengan menggunakan Theory of Planned Behavior, disimpulkan bahwa norma subjektif tidak memiliki pengaruh signifikan terhadap niat untuk mengkonsumsi daging halal. Begitu pula dengan hasil penelitian dari Omar, et al. (2012), menemukan bahwa norma subjektif tidak berpengaruh terhadap niat pembelian produk makanan halal. Hasil dua penelitian tersebut sangat kontras dengan apa yang ditemukan oleh Alam dan Sayuti (2011), serta Mukhtar dan Butt (2012), yang mengungkapkan bahwa norma subjektif berpengaruh positif terhadap niat pembelian produk makanan halal. Namun, semua penelitian tersebut menemukan hasil yang sama dalam variabel sikap dan kontrol perilaku, bahwa kedua variabel tersebut berpengaruh terhadap niat pembelian produk dan atau produk makanan halal. Selanjutnya, variabel religiusitas yang dimunculkan oleh Mukhtar dan Butt (2012), disinyalir belum begitu jelas pengaruhnya terhadap niat pembelian produk halal dikarenanakan terjadi adanya perbedaan hasil temuan antara kondisi religiusitas internal dan eksternal yang ada dalam tiap individu.

Penelitian ini dilakukan untuk menguji sejauh mana pengaruh sikap, norma subjektif, kontrol perilaku terhadap niat untuk memilih jasa halal beauty center, serta peran religiusitas sebagai variabel pemoderasi. 


\section{HIPOTESIS PENELITIAN}

Berkait dengan pengukuran aspek religiusitas, penelitian ini menggunakan konsep islamic religiousity index yang dikonstruk oleh Shabir dan Rehman (2010) dimana di dalamnya terdapat lima dimensi utama yaitu dimensi ideologi; dimensi ritual; dimensi intelektual; dimensi konsekuensional; dan dimensi pengalaman. Adapun untuk pengukurannya, dalam penelitian ini menggunakan model yang digagas oleh R. Stark dan C.Y Glock (1968) dan dipadukan dengan Islamic Religiosity Index (Shabbir, 2007), yaitu dengan membagi religiusitas seseorang ke dalam lima dimensi, yaitu:

\section{Dimensi Ritual}

Dalam Islamic Religiosity Index, dimensi ritual meliputi salat lima waktu setiap hari; puasa di bulan ramadan; membaca al-quran; dan ibadah haji.

\section{Dimensi Ideologis}

Dalam Islamic Religiosity Index, dimensi ideologis meliputi keyakinan atas semua aqidah (konsep keimanan dalam Islam) dasar; meyakini Nabi Muhammad sebagai nabi terakhir; dan meyakini keEsa-an Allah.

\section{Dimensi Intelektual}

Dalam Islamic Religiosity Index, dimensi intelektual meliputi menghindari aktivitas yang berhubungan dengan kesyirik-an; menghindari penghasilan yang haram; menghindari dosa besar dan kecil; pengetahuan tentang ilmu-ilmu agama yang penting danmendasar; motivasi untuk mengikuti setiap petunjuk Islam dalamsetiap aspek kehidupan.

\section{Dimensi Pengalaman}

Dalam Islamic Religiosity Index, dimensi pengalaman meliputi perasaanperasaan menyesal pada saat berbuat dosa; perasaan akan godaan dari setan; perasaan takut kepada Allah; perasaan dihukum oleh Allah pada saat melakukan kesalahan; dan perasaan senang tatkala melihat orang lain mengikuti ajaran Islam.

\section{Dimensi Konsekuensi}

Dalam Islamic Religiosity Index, dimensi konsekuensi meliputi komitmen untuk selalu menghormati orang lain berdasarkan petunjuk Islam; komitmen untuk tidak melakukan aktivitas yang dapatmenyakiti orang lain; komitmen untuk selalu berusaha untuk menolong orang lain yang membutuhkan pertolongan; komitmen untuk selalu jujur dan adil; dan komitmen untuk tidak menghina dan mempermalukan orang lain.

\section{Konsep Halal.}

Konsep halal dalam Islam mempengaruhi banyak aspek kehidupan para penganutnya. Secara sederhana, halal bermakna boleh atau tidak dilarang. Pada umumnya konsep ini dianggap hanya mengatur masalah makanan dan minuman, padahal sesungguhnya konsep ini mengatur tentang semua hal, tanpa terkecuali, seperti dalam hal produk kecantikan, layanan kesehatan, layanan perawatan badan dan lain-lain. (Kamali, 2003).

\section{Hipotesis}

Alam dan Sayuti (2011) menyatakan bahwa sikap merupakan salah satu faktor penting yang mempengaruhi niat pembelian produk makananan halal karena kosumen yang memiliki sikap positif terhadap produk halal cenderung untuk memiliki niat pembelian yang sangat tinggi untuk membeli produk makanan halal. Dalam konteks penelitian yang sama, Bonne, et al. (2007) dalam penelitiannya tentang konsumsi daging halal di Perancis menemukan bahwa sikap terhadap produk daging halal berpengaruh positif terhadap niat untuk mengkonsumsi produk daging halal. Sementara itu, Mukhtar dan Butt (2012) juga mengungkapkan bahwa sikap terhadap produk halal berpengaruh sangat positif terhadap niat untuk membeli setiap produk yang halal.

Hipotesis 1: Sikap terhadap halal beauty center berpengaruh positif terhadap niat untuk memilih jasa halal beauty center. 
Konsep norma subjektif didefinisikan sebagai sebuah penilaian pribadi setiap individu sebagai sebuah reaksi dari tekanan lingkungan untuk melakukan atau tidak melakukan suatu perilaku tertentu. Apabila kondisi lingkungannya mendukung dia untuk melakukan perilaku yang dikehendaki, maka individu tersebut akan sangat mungkin untuk melakukan perilaku tersebut (Alam dan Sayuti, 2011). Dalam konteks penelitian ini, apabila norma yang ada di sekitar seseorang mendukung keyakinan dia bahwa produk halal itu adalah baik, maka niat untuk memilih produk halal akan semakin tinggi(Omar et al., 2012). Bonne, et al. (2007) menemukan bahwa norma subjektif tidak berpengaruh terhadap niat untuk mengkonsumsi daging halal. Hal tersebut sejalan dengan dengan temuan dari Omar et al. (2012) yang mengatakan bahwa norma subjektif tidak berpengaruh terhadap niat untuk membeli produk halal. Berbeda dengan apa yang ditemukan oleh Bonne et al. (2007) dan Omar, et al. (2012), Alam dan Sayuti (2011) dalam penelitiannya menemukan bahwa norma subjektif berpengaruh positif terhadap niat pembelian sebuah produk makanan halal. Temuan tersebut sejalan dengan hasil penelitian Mukhtar dan Butt (2012) yang mengatakan bahwa norma subjektif berpengaruh positif terhadap niat pembelian produk halal. Dalam konteks penelitian yang berbeda, Huda et al. (2012) menemukan bahwa norma subjektif berpengaruh positif terhadap niat seseorang untuk membayar zakat.

Selain itu, masih dalam konteks yang berbeda, Kamariah dan Muslim (2007) membuktikan bahwa norma subjektif memiliki pengaruh yang positif terhadap niat pembelian di pasar on-line.

Hipotesis 2: Norma subjektif berpengaruh positif terhadap niat untuk memilih jasa halal beauty center.

Konsep kontrol perilaku, menunjukkan aneka persepsi seseorang tentang kemampuannya untuk melakukan suatu perilaku tertentu, dimana semua persepsi tersebut mengalami fluktuasi dan bergantung kepada sifat pembelajaran dan keyakinan-diri untuk memunculkan suatu perilaku seseorang (Ajzen, 2006; Bandura,1977). Gopi dan Ramayah (2007) mengungkapkan bahwa aspek kontrol perilaku terbukti berpengaruh positif dan dapat menjadi anteseden dari niat untuk menggunakan layanan perdagangan saham di internet. Sementara itu, Sayuti dan Alam (2011) menemukan bahwa aspek kontrol perilaku, meskipun tidak menjadi faktor yang begitu dominan, tetap berpengaruh positif terhadap niat untuk membeli produk makanan halal. Lebih lanjut, dalam penelitian tentang niat untuk mengunjungi hotel, Kun-Shan dan Yi-Man (2011) membuktikan bahwa aspek kontrol perilaku secara signifikan dapat menjadi prediktor terhadap niat untuk mengunjungi hotel. Pengaruh dari aspek kontrol perilaku ini pun telah dibuktikan dalam konteks niat untuk membayar zakat oleh Huda, et al. (2012), dimana dalam penelitian tersebut ditemukan bahwa kontrol perilaku berpengaruh terhadap niat muzaki untuk membayar zakat. Sementara itu, Omar (2012) pun mengungkapkan bahwa aspek kontrol perilaku memiliki pengaruh positif terhadap niat untuk membeli produk halal.

Hipotesis 3: Kontrol perilaku berpengaruh positif terhadap niat untuk memilih jasa halal beauty center.

Muhamad dan Mizerski (2010) mengungkapkan bahwa agama merupakan suatu aspek yang dapat mempengaruhi perilaku konsumen. Lebih lanjut, Fam, et al (2002) menyatakan bahwa komitmen beragama atau religiusitas memiliki peran yang sangat penting dalam pembentukan komponen-komponen perilaku seseorang. Sehingga, dapat dikatakan bahwa agama dapat mempengaruhi perilaku seseorang dan kehidupannya secara umum (Ebaugh 2002; Poloma dan Pendlenton 1990; Sloan, et al. 1999; Woods, et al. 1999).

Hipotesis 4 a : Religiusitas memoderasi hubungan antara sikap terhadap niat untuk memilih jasa halal beauty center. 
Hipotesis 4 b : Religiusitas memoderasi hubungan antara norma subjektif terhadap niat untuk memilih jasa halal beauty center.

Hipotesis 4 c : Religiusitas memoderasi hubungan antara kontrol perilaku terhadap niat untuk memilih jasa halal beauty center.

\section{METODE PENELITIAN}

\section{Penelitian ini menggunakan metode} survey, dengan kuesioner sebagai instrumen untuk mengumpulkan data. Kuesioner theory of planned behavior diadaptasi dari ajzen (2006), terdiri dari item pertanyaan untuk variabel sikap 5 item $(\alpha=0.872)$, variabel norma subjektif 6 item $(\alpha=0.865)$, variabel kontrol perilaku 4 item $(\alpha=0.748)$, variabel niat 4 item $(\alpha=0.965)$, sedangkan untuk mengukur religiusitas, peneliti menggunakan kuesioner berdasarkan islamic religiosity index dari Shabir dan Rehman (2010), terdiri dari 5 item $(\alpha=0.807)$. Sampel penelitian diambil secara purposive dimana responden yang dipilih hanya perempuan muslim. Kuesioner yang disebarkan sebanyak 150, sedangkan yang kembali dan terisi dengan baik sebanyak 120, berusia 17-19 tahun (20\%), $20-30$ tahun (45\%), 31-40 (16,67\%), 41-50 $(10,83 \%)$, diatas 50 tahun ( $5 \%)$. Tingkat pendidikan terakhir responden: SD (4,17\%), SMP $(11,67 \%)$, SMA $(54,17 \%)$, D3 (8,33\%), S1 (20\%), S2 (1,67\%). Profesi: PNS (5,83\%), karyawan swasta (12,5\%), Wiraswasta (12,5\%), Mahasiswa $(42,5 \%)$, Pelajar $(3,33 \%)$, Ibu rumah tangga $(23,33 \%)$.

Pengujian hipotesis dilakukan melalui uji regresi berganda dengan menggunakan uji $\mathrm{F}$ dan uji t, sedangkan untuk menguji pengaruh moderasi pada penelitian ini digunakan metode uji Chow.

\section{HASIL DAN PEMBAHASAN \\ Hasil uji Hipotesis}

Hasil uji $\mathrm{t}$ atau uji hipotesis penelitian disajikan dalam Tabel 1.

Tabel 1. Hasil uji t

\begin{tabular}{lll}
\hline Variabel & $\mathrm{t}_{\text {hitung }}$ & $\mathrm{t}_{\text {tabel }}$ \\
& & \\
Sikap (x1) & 2,078 & 1,981 \\
Norma Subjektif (x2) & 3,022 & 1,981 \\
Kontrol Perilaku (x3) & $-0,107$ & 1,981
\end{tabular}

Sumber : Diolah dari hasil penelitian

Selanjutnya, untuk menguji pengaruh moderasi dari variabel religiusitas terhadap hubungan antara semua variabel independen dengan variabel dependen, digunakan metode uji Chow. Uji Chow dilakukan dengan cara mencari nilai $F$ hitung dengan rumus sebagai berikut:

$\mathrm{F}=\frac{(\mathrm{SSRT}-\mathrm{SSRR}) / \mathrm{K}}{(\mathrm{SSRR}) / \mathrm{n} 1+\mathrm{n} 2-2 \mathrm{k}}$

Makna sikap dalam konteks Theory of Planned Behavior diartikan sebagai sebuah rangkaian evaluasi seseorang dalam menilai baik dan buruknya suatu perilaku tertentu, dalam hal ini niat untuk memilih jasa halal beauty center. Penilaian positif terhadap sebuah objek tertentu cenderung untuk meningkatkan minat terhadap objek tersebut. Selanjutnya, Norma subjektif dalam penelitian ini diartikan sebagai seberapa pentingkah referensi atau saran dari orang lain yang dianggap penting oleh seseorang untuk melakukan suatu perilaku. Rekomendasi orang terdekat menjadi salah satu faktor penting untuk dipertimbangkan oleh individu sebelum memutuskan untuk memilih jasa halal beauty center. Berbeda dengan dua variabel sebelumnya, variabel kontrol perilaku diketahui tidak berpengaruh positif dan signifikan terhadap niat untuk memilih jasa halal beauty centre. Sementara itu, hasil temuan dalam penelitian ini menunjukkan bahwa religiusitas memoderasi hubungan antara sikap individu terhadap niat untuk memilih 
jasa halal beauty center. Faktor religuisitas dapat mengontrol kecenderungan seseorang untuk selalu menyandarkan sikap dan penilaian mereka kepada nilai-nilai yang ada di dalam agama (Islam) dan bagaimana dia menyikapi saran atau rekomendasi dari orang-orang terdekatnya, yang dalam hal ini adalah niat untuk memilih jasa halal beauty center.

Hasil penelitian ini mengkonfirmasi beberapa hasil penelitian sebelumnya yang menyatakan bahwa aspek sikap merupakan faktor yang berpangaruh signifikan terhadap niat untuk memilih dan atau membeli produk (makanan) halal. Bonne dan Karijin, et al. (2007) dalam penelitiannya tentang faktor-faktor yang mempengaruhi niat untuk mengkonsumsi daging halal, menemukan bahwa sikap positif merupakan salah satu penentu dari niat untuk mengkonsumsi daging halal. Lebih lanjut, Alam dan Sayuti (2011) pun menemukan hal yang sama dalam penelitiannya tentang aplikasi Theory of Planned Behavior dalam pembelian produk halal, yaitu bahwa sikap berpengaruh positif dan signifikan terhadap niat untuk membeli makanan halal. Demikian pula dengan hasil penelitian Mukhtar dan Butt (2012) yang menyatakan bahwa sikap berpengaruh positif terhadap niat untuk membeli produk-produk halal. Lebih lanjut, hasil penelitian ini pun mendukung beberapa hasil penelitian sebelumnya yang meneliti tentang peran norma subjektif dalam hal menentukan niat. Alam dan Sayuti (2011) menyatakan bahwa aspek norma subjektif atau referensi berkorelasi positif dan signifikan terhadap niat untuk membeli makanan halal. Selain itu, Mukhtar dan Butt (2012) pun dalam penelitiannya menemukan bahwa norma subjektif merupakan aspek yang dapat mendikte seseorang untuk bersikap positif dan menjadikan seseorang berniat untuk membeli produk-produk halal. Sementara itu, Alam dan Sayuti (2011) menemukan bahwa kontrol perilaku bukan merupakan prediktor yang penting terhadap niat.

\section{KESIMPULAN}

Simpulan dalam penelitian ini adalah bahwa dua variabel dalam theory of planned behavior, sikap dan norma subjektif, berpengaruh positif terhadap niat individu untuk memilih jasa halal beauty center. Dua hipotesis pada variabel sikap dan norma subjektif didukung oleh data, sedangkan variabel kontrol perilaku tidak, dan diketahui bahwa aspek religiusitas memoderasi hubungan antara ketiga variabel tersebut dengan variabel niat untuk memilih jasa halal beauty center. Semakin positif penilaian individu terhadap suatu objek perilaku, semakin tinggi pula kecenderungan individu untuk mengarah kepada perilaku tersebut. Semakin tinggi tingkat keterbukaan seseorang terhadap orang terdekatnya, semakin tinggi pula kecenderungannya untuk melaksanakan hal-hal yang disarankan oleh orang terdekatnya, dan religiusitas mampu menjadi aspek pengontrol dalam kedua hal tersebut.

\section{IMPLIKASI MANAJERIAL}

Penelitian ini bersifat empiris, sehingga hasil temuan yang didapatkan dapat dimanfaatkan oleh para pelaku bisnis halal beauty center sebagai bahan pertimbangan untuk mengetahui karakteristik para pelanggannya.

Dari penelitian ini diketahui bahwa sikap muslimah, yang dalam hal ini didefinisikan sebagai suatu evaluasi muslimah terhadap keberadaan halal beauty center, merupakan salah satu faktor yang mempengaruhi kecenderungan muslimah untuk memilih jenis layanan ini, sehingga dari temuan ini hendaknya para pemasar dan atau manajemen halal beauty center untuk terus mempertahankan citra syar'i-nya sebagai sebuah jasa layanan kecantikan yang berkomitmen untuk menjunjung tinggi nilai-nlai Islam dalam operasionalnya, dan yang paling utama adalah mampu menjadi sarana untuk mengakomodasi komunitas muslimah yang sangat berkomitmen dalam menjaga auratnya. 
Selain itu, penelitian ini pun menemukan bahwa norma subjektif atau aspek pemberi referensi, baik keluarga, teman maupun kolega yang memberikan dorongan kepada muslimah untuk memilih halal beauty center pun menjadi faktor yang mempengaruhi kecenderungan niat muslimah untuk memilih halal beauty center, sehingga apabila dikaitkan dengan konsep word of mouth dalam marketing maka hendaknya para pemasar halal beauty center untuk menyarankan para wanita muslimah yang telah menjadi pelanggan setiauntuk dengan suka rela menyebarkan informasi tentang keberadaan halal beauty center serta mengajak orang-orang di sekitarnya, baik kolega maupun sanak keluarga, supaya memilih halal beauty center.

Kemudian yang paling penting dari semuanya adalah diketahui bahwa semakin tinggi kecenderungan religiusitas seorang muslimah maka semakin baik pula sikap dan norma subjektif muslimah tersebut, yang kemudian akan menguatkan hubungan pengaruh diantara kedua variabel anteseden tersebut terhadap kecenderungan untuk memilih halal beauty center, sehingga para pelaku bisnis halal beauty centertidak perlu khawatir dengan konsep unik yang menonjolkan sisi religi dalam hal pelayananan, karena semakin pelayananannya sesuai dengan syariat Islam maka semakin dapat memberikan kenyamanan bagi wanita muslimah yang religius.

\section{DAFTAR PUSTAKA}

Abdurrahman, H. (1998). Diskursus Islam, Politik, dan Spiritual. Bogor: AlAzhar Press.

Adawiyah, W. R. (2011). The Relationship Between Soft TQM and Work Related Outcome: The Moderating Impact of Spirituality at The Workplace. Unspublished doctoral dissertation, Universuty of Utara Malaysia.
Ajzen, I. (2006). Constructing A Theory Of Planned Behavior Questionnaire. Diambil dari : www.people.umass.edu (diakses pada 12 Mei 2013)

Alam, S. S., \& Sayuti, N. M. (2011). Applying the theory of Planned Behavior in Halal food purchasing. International Journal of Commerce and Management, 21(1), 8-20.

Alam, S. S., M., Rohani., \& Hisham, B. (2011). Is religiosity an important determinant on Muslim consumer behaviour in Malaysia?. Journal of Islamic Marketing, 2(1), 83-96.

Ancok, J., \& Fuad, A. S. (1995). Psikologi Islam : Solusi Islam Atas ProblemProblem Psikologi. Yogyakarta: Pustaka Pelajar.

Bandura, A. (1977). Self-efficacy Mechanism in Human Agency. American Psychologist (37), 122-147.

Bonne, Karijin, et al. (2007). Determinants of halal meat consumption in France. British Food Journal, 109(5).

Ebaugh, H. R. (2002). Return of the Sacred: Reintegrating Religion in the Social Sciences. Journal of the Scientific Study of Religion, 41 (3), 385-395.

Francis, J. J., Eccles, M. P., Johnston, M., Walker, A., Grimshaw, J., Foy, R., et al. (2004). Constructing Questionnaires Based on the Theory of Planned Behavior: A Manual for Health Services Researchers. University of Newcastle, Centre for Health Services Research, Newcastle.

Mowen, J. C. \& Minor, M. (2002). Perilaku Konsumen. Jakarta: Erlangga. 
Fam, K. S., Waller, D.S. \& Erdogan, B. Z. (2002).The influence of religion on attitudes towards the advertising of controversial products. European Journal of Marketing. 38(5/6), 537555.

Kun-Shan, W. \& Yi-Man, T. (2011). Applying the extended theory of planned behavior to predict the intention of visiting a green hotel. African Journal of Business Management Vol. 5(17), 7579-7587.

Muhamad, N., \& Mizerski, D. (2010). The constructs mediating religions' influence on buyers and consumers. Journal of Islamic Marketing, 1(2), 124-135.

Mukhtar, A., \& Butt, M. (2012). Intention to choose Halal products: the role of religiosity. Journal of Islamic Marketing, 3(2).

Omar, K. M., et al. (2012). The Direct Effects of Halal Product Actual Purchase Antecedents among the International Muslim Consumers. American Journal of Economics. Special Issue: 87-92.

Peter, J. P. \& Olson, J. C. (2000). Consumer Behavior, Perilaku Konsumen dan Strategi Pemasaran. Jakarta: Erlangga.

Poloma, M. M. \& Pendelton, B. F. (1990). Religious Domains and General WellBeing. Social Indicators Research, 22, 255-276.

Shabbir, M. S. \& Rehman, A. (2010). The relationship between religiosity and new product adoption. Journal of Islamic Marketing, 1(1), 63-69.
Sloan R. P., Bagiella, E. \& Powell., T. (1999). Religion, Spirituality, and Medicine. Lancet, 353 (February 20), 664-667.

Stark, R., \& Glock, C. Y. (1968). American Piety: The Nature of Religious Commitment. Berkeley: University of California Press.

Suhardiyanto (2001). Pendidikan Religiusitas. Jogjakarta: Kanisius.

Sun, S., Goh, T., Fam, K., \& Xue, Y. (2011). The influence of religion on Islamic mobile phone banking services adoption. Journal of Islamic Marketing. 3(1), 81-98.

Woods, T. E., Antoni, M. H., Ironson, G. H. \& Kling, D. W. (1999). Religiosity is Associated with Affective and Immune Status in Symptomatic HIVInfected Gay Men. Journal of Psychosomatic Research, 46 (February), 165-176. 